ROCZNIKI PEDAGOGICZNE

Tom 13(49), numer $4-2021$

DOI: http://doi.org/10.18290/rped21134.5

DANUTA OPOZDA

\title{
CZYSTOŚĆ JAKO WARTOŚĆ W OPINII MŁODZIEŻY O RÓŻNYM POCZUCIU TOŻSAMOŚCI PŁCIOWEJ W ŚWIETLE BADAŃ PILOTAŻOWYCH
}

\begin{abstract}
WSTĘP
Współczesna młodzież żyje w czasach wielkich transformacji technicznych, gospodarczych, ustrojowych i kulturowych. Są one przejawem i jednocześnie podstawą postępu, ale również stają się źródłem zmian w obyczajowości i stylach życia. Bywa, że stają się też źródłem zagrożeń na drodze ku dojrzałej osobowości i rozwoju osoby ludzkiej. Zmiany społeczno-kulturowe, pluralizm aksjologiczny, a szczególnie zmiany w systemach wartości moralnych prowadzą czasami do zagubienia, co wyraża hasło eksponowane przez jedną z nastolatek: „System wartości w przebudowie - przepraszamy za utrudnienia”. Proces zmian, dokonujący się w mentalności ,globalnego nastolatka” (Melosik, 2013), stał się ważnym przedmiotem badań społecznych nad młodzieżą - jej światopoglądem, systemem wartości, percepcji siebie, otoczenia, w którym żyje, czy też relacji z drugim człowiekiem. Zmiany te są ważne, a wręcz kluczowe dla funkcjonowania młodych ludzi w rolach społecznych aktualnych i przyszłych. A mając na uwadze role małżeńskie i rodzinne przemiany ostatnich dekad w zakresie wartości moralnych są szczególnie istotne. Nieustannie interesujące jest zatem jak sama młodzież odnosi się i wypowiada w zakresie rozumienia i urzeczywistniania wartości moralnych we własnym życiu. Dla życia małżeńskiego i sfery seksualności człowieka, integralnie włączonej w jego ogólną dojrzałość, ważna jest internalizacja wartości czystości przedmałżeńskiej. Do tego zagadnienia odnoszę się poniżej.
\end{abstract}

Dr hab. DANuTA OpozDA, prof. KUL - Instytut Pedagogiki, Wydział Nauk Społecznych Katolickiego Uniwersytetu Lubelskiego Jana Pawła II; adres do korespondencji: Al. Racławickie 14, 20-950 Lublin; e-mail: danuta.opozda@kul.pl; ORCID: https://orcid.org/0000-0002-4715-9241 
Niniejszy tekst jest próbą włączenia się do opisu i refleksji nad zmianami dotyczącymi, najogólniej rzecz ujmując, wartości młodzieży. Celem jest przedstawienie opinii młodzieży na temat czystości przedmałżeńskiej jako wartości. Artykuł ma formę komunikatu z przeprowadzonych badań, które miały charakter pilotażowy. Przedmiotem poznania prezentowanych badań była wartość czystości w opinii młodzieży, przy czym uwzględniono poczucie tożsamości płciowej badanych, uznając tą zmienną jako ważny predyktor pozostający także pod silnym wpływem współczesnych zmian kulturowych. Ponadto dla funkcjonowania w rolach rodzinnych ważne jest zarówno rozumienie czystości przedmałżeńskiej jak i określenie własnej tożsamości płciowej.

\section{CZYSTOŚĆ JAKO WARTOŚĆ I POCZUCIE TOŻSAMOŚCI PŁCIOWEJ MŁODZIEŻY - PODSTAWOWE USTALENIA TEORETYCZNE}

Czystość ma konotacje pozytywne, mówimy czyste niebo, powietrze, dźwięk, ręce, serce, rozum, umysł, a więc wolne od zanieczyszczeń, zabrudzenia, zakłamania, zniekształcenia, przestępstw i oszustw. Klarowne, jasne, obecne w swej podstawowej istocie. W sferze życia moralnego czystość oznacza zacność, szlachetność i jednoznaczność, krystaliczność i nieskazitelność charakteru, ale zawsze w odniesieniu do wartości moralnych. W obyczajowości różnych kultur, w systemach religijnych i koncepcjach człowieka czystość rozumiana jest jako cnota. Oznacza zatem przestrzeganie zasad obowiązującej etyki, jest pożądaną, dodatnią cechą człowieka świadczącą o jego prawości i niewinności. W chrześcijaństwie czystość serca oznacza dostosowanie umysłu i woli do Bożych wymagań w zakresie czystości serca, ciała i wiary (Katechizm Kościoła Katolickiego, 1994, s. 563). Źródła, rozumienie i uzasadnienie cnoty (także cnoty czystości) odnajdujemy jednak nie tylko w uniwersalności chrześcijaństwa, ale również, jak zauważa Paweł Skrzydlewski, odnajdujemy w antropologii i metafizyce oraz pochodnej do nich etyce życia indywidualnego, rodzinnego i społecznego. Brak zrozumienia dla wychowania do cnót wynika ,z odrzucenia realistycznego obrazu świata i człowieka na rzecz różnych koncepcji i stanowisk, które niewiele mają wspólnego z prawdą o świecie i człowieku" (Skrzydlewski, 2021, s. 216). W refleksji nad cnotami niewieścimi wspomniany autor stwierdza: „Współczesnemu człowiekowi, pozbawionemu realistycznej metafizyki i antropologii, także autentycznej więzi z Bogiem, trudno zrozumieć, że cnoty niewieście wyrastają z pokory, idącego za nią posłuszeństwa, owocują zaś pełnią życia osobowego, do którego zresztą same prowadzą" (Skrzydlewski, 2021, s. 216). 
Cnota czystości odnosi się także do sfery seksualności człowieka i oznacza zasadę zachowania porządku moralnego w tym obszarze, a więc w obszarze miłości między kobietą a mężczyzną. W chrześcijaństwie oznacza to między innymi wymagane zachowanie czystości - wstrzemięźliwości seksualnej w przypadku bezżenności, narzeczeństwa, a w małżeństwie wymagane jest dochowanie wierności wobec współmałżonka. Na czystość wskazują jednoznacznie przykazania Dekalogu: szóste - nie cudzołóż i dziewiąte - nie pożądaj żony bliźniego swego. Posiadają one wnikliwe wyjaśnienia i interpretacje odwołujące się do personalizmu chrześcijańskiego, szczególnie normy personalistycznej, zasady nieużywania osoby i płciowości człowieka (Jan Paweł II, 1986; Wojtyła, 1982).

Zachowanie czystości przedmałżeńskiej łączy się z internalizacją normy etycznej, uwewnętrznieniem wartości, uznaniem jej za własną i przekonaniem o jej słuszności. Czystość przedmałżeńska jako wartość zostaje więc umiejscowiona w systemie wartości wśród kilku/kilkunastu innych i, jak i one, pełni funkcje orientacyjne, motywacyjne, regulacyjne i interpretacyjne w zachowaniu człowieka (Wojciszke, 2002). Ma udział w kształtowaniu się postaw i określaniu światopoglądu. Czystość przedmałżeńska właściwie rozumiana jest wyrazem dojrzałości, panowania i kontroli popędu i pożądliwości, odpowiedzialności za siebie i poszanowania drugiej osoby. Nie stanowi ograniczenia, zniewolenia czy lęku. Czystość zakłada, iż ,to, co jest najbardziej intymne i najmocniej związane z miłością oraz zaufaniem, można ofiarować tylko jednej osobie i tylko od jednej osoby można przyjąć ją w darze" (Dziewiecki, 2011, 2006, s. 146). Niektórzy młodzi ludzie podzielają takie poglądy i chcą żyć w czystości przedmałżeńskiej ceniąc ją jako zadanie, dar i odpowiedzialność za siebie i za drugiego (Ostrowska, 2017, Jazukiewicz, Rojewska, 2017).

Urzeczywistnianie wartości czystości przedmałżeńskiej staje się dziś dużym wyzwaniem nie tylko dla samych młodych, ale również wyzwaniem dla rodziców, nauczycieli i wychowawców wobec naporu liberalnych koncepcji, erotyzacji dzieci i młodzieży, promowania swobody obyczajowości i odłączenia sfery seksualnej od integralnej struktury i rozwoju osoby. Stąd duże zapotrzebowanie na integralne wychowanie wspierające dzieci i młodzież w osiąganiu dojrzałej osobowości, potrzeba wzorów i promowania wartości osoby, wychowania do odpowiedzialności i dojrzałej relacji z drugim.

Spostrzeganie i rozumienie czystości przedmałżeńskiej jako wartości, pozytywne opiniowanie wszelkich jej przejawów i dążenie do jej zachowania jest uwarunkowane wielowymiarowo. Zależy od kontekstów socjokulturowych, rówieśniczego otoczenia społecznego, wychowania rodzinnego oraz kultury i wartości domu rodzinnego, a w okresie adolescencji także od indywidualnych właściwości, formułującego się systemu wartości i zaangażowania religijnego, 
percepcji i rozumienia siebie i świata. Wśród indywidualnych właściwości moderatorem akceptacji i uznania czystości przedmałżeńskiej może być poczucie tożsamości płciowej.

Tożsamość płciowa jest tak zwaną „wystającą tożsamością” (efekt „wystawania") obok wieku i rasy, co oznacza, że jest łatwo identyfikowana przez otoczenie i dostarcza innym szybkich danych aktywizujących ich schematy społeczne czy stereotypy (Miluska, 1996). Tożsamość płciowa jest analizowana na trzech poziomach. Na poziomie biologicznym jako zespół cech płciowych, na poziomie społecznym jej odpowiednikiem jest funkcjonowanie w rolach społecznych (nie tylko bezpośrednio związanych z płcią), a na poziomie psychologicznym tożsamość płciowa wyraża się jako psychiczna akceptacja dla własnej płciowości. Poczucie tożsamości płciowej, inaczej płeć psychologiczna jest podmiotowym doświadczaniem siebie jako osoby o określonej płci.

Tożsamość płciowa implikuje zagadnienia rozwojowe i może być rozumiana jako uniwersalna, wspólna i indywidualna zmiana rozwojowa, implikuje także zagadnienia wychowawcze, co ogólnie oznacza poszukiwanie w teorii i praktyce edukacyjnej odpowiedzi na pytanie jak wspierać dzieci i młodzież w procesach rozwoju tożsamości płciowej oraz jakie ma ona znaczenie $\mathrm{w}$ funkcjonowaniu rodziców, nauczycieli i innych w rolach wychowawczych (Opozda, 2012).

W dobie różnorakich dyskusji, kontrowersji i sporów, forsowania redukcjonistycznych koncepcji człowieka, warto podkreślić iż z racji, że tożsamość płciowa jest zjawiskiem biospołecznym, jej kompletne, całościowe i dogłębne badania wymagają adekwatnego podejścia epistemologicznego, a więc zastosowania modelu zintegrowanego (Mandal, 2003). Badanie w modelu socjobiologicznym lub socjokulturowym (tak zwane studia gender) ma zawsze charakter wycinkowy, fragmentaryczny i dość zawężony, bo z jednej strony redukuje tożsamość płciową do rezultatu zmian ewolucyjnych, z drugiej do wpływu czynników społeczno-kulturowych mających znaczenie jako jedynych. Spór między zwolennikami modelu socjobiologicznego a socjokulturowego wpisuje się czytelnie w dyskusję natura vs kultura i opozycyjny układ teorii biologistycznych (natawistycznych) i środowiskowych, a w radykalnej postaci oznacza walkę o dominację jednych nad drugimi.

W prezentowanych w niniejszym komunikacie badaniach przyjęto świadomie zawężone rozumienie tożsamości płciowej jako tej zmiennej będącej pod silnym wpływem czynników kulturowych w procesie jej formowania się. Oznacza to, że warunki społeczno-kulturowe mają istotne znaczenie dla określania cech związanych z faktem bycia kobietą i mężczyzną. Osoba identyfikuje się w różnym stopniu z dostępnymi w kulturze wzorcami kobiecości i męskości oraz asymiluje z różną intensywnością zarówno tak zwane cechy kobiece jak i męskie. Kształtowanie 
cech psychicznych związanych z płcią jest silnie warunkowane kulturowymi schematami płci, a więc atrybutami kobiecości i męskości typowymi dla danej kultury i społeczności. Schematyzm płci jest włączony w strukturę ,ja” i pełni funkcje regulacyjne i orientacyjne w zachowaniu jednostki i percepcji świata. Podejście społeczno-konstruktywistyczne, a także teorie społecznego uczenia się podkreślają fakt, iż jednostka w ciągu życia uczy się kulturowych definicji kobiecości i męskości. Rodzina i instytucje, głównie o charakterze edukacyjnym, są ich przekazicielami. Wyjątkowo istotne miejsce w tym przekazie zajmuje proces socjalizacji, dzięki któremu transmitowane są kulturowe wzorce kobiecości i męskości.

W reprezentatywnej dla tego podejścia teorii Sandry L. Bem (2000) przyjęto, że kobiecość i męskość to dwa odrębne wymiary osobowości kształtowane pod silnym wpływem warunków socjokulturowych. Stopień identyfikacji jednostki z kulturowymi wzorcami kobiecości i męskości określa jej poczucie tożsamości płciowej. Konfiguracja natężenia atrybutów, uznanych w danej kulturze za typowo kobiece lub męskie, w rezultacie prowadzi do ustalenia typów płci psychologicznej (tożsamości płciowej).

- osoby określone seksualnie (stypizowane) (przyjmują wzorzec kulturowy kobiecości lub męskości zgodnie z płcią biologiczną, cechy psychiczne odpowiadają płci biologicznej, jednostka ma silną motywację do utrzymania wizerunku własnej osoby zgodnego z kulturowymi standardami);

- osoby androgyniczne (wysokie nasycenie cech kobiecych i męskich niezależnie od płci biologicznej);

- osoby nieokreślone seksualnie (w niewielkim stopniu ukształtowane są cechy kobiece i męskie niezależnie od płci biologicznej, w określaniu siebie jest niskie nasycenie kulturowych atrybutów kobiecości i męskości);

- osoby krzyżowo określone seksualnie (cechy psychiczne, którymi jednostka określa siebie w standardzie kulturowym, odpowiadają przeciwnej płci niż jej płeć biologiczna).

\section{PRZEDMIOT, PROBLEM I NARZĘDZIA BADAŃ}

Czystość przedmałżeńska jako przedmiot poznania może być sprowadzona do różnych kategorii (konstruktów badawczych) na przykład: jako wartość w hierarchii wartości badanych osób, jako postawa badanych wobec czystości czy jako wiedza potoczna o czystości przedmałżeńskiej wyrażona w przekonaniach, poglądach i opiniach badanych. W przedstawionych badaniach przedmiotem 
poznania była opinia młodzieży na temat czystości przedmałżeńskiej ${ }^{1}$ Założono, że opinia ta może być zróżnicowana poczuciem tożsamości płciowej badanych. Problem główny zawarty został w pytaniu: Jaka jest opinia młodzieży, różniacej się poczuciem tożsamości plciowej, na temat czystości przedmatżeńskiej? Schemat pytań szczegółowych dotyczył kolejno rozumienia czystości przedmałżeńskiej, motywacji do jej zachowania, jej uwarunkowań i znaczenia. Zmienną zależną była opinia na temat czystości przedmałżeńskiej, natomiast zmienną niezależną typ poczucia tożsamości płciowej. Hipotezę główną sformułowano następująco: Typ poczucia tożsamości płciowej różnicuje opinie młodzieży na temat czystości przedmatżeńskiej i adekwatnie przyjęto, że opinia na temat rozumienia, motywacji, uwarunkowań oraz znaczenia różnicowana jest poczuciem tożsamości płciowej.

Obie zmienne zoperacjonalizowano w narzędziach badawczych. Opinię młodzieży badano z zastosowaniem ankiety własnej konstrukcji. Ankieta zawierała 31 pytań, w tym dwa pierwsze pytania to metryczka - płeć i wiek, pozostałe mające formę otwartą i zamkniętą dotyczyły zagadnień sygnalizowanych w pytaniach badawczych. Do pomiaru poczucia tożsamości płciowej posłużono się Inwentarzem do Oceny Płci Psychologicznej (IPP). Narzędzie tworzą dwie skale: kobiecości i męskości. Każda ze skal zawiera po 15 cech charakteryzujących osobno kobiety i mężczyzn. Zadaniem osoby badanej jest oznaczenie na pięciopunktowej skali ocen w jakim stopniu każda z cech jest dla niej charakterystyczna. Obliczony oddzielnie dla skali kobiecości i męskości wynik umożliwia określenie typu płci psychologicznej osoby badanej i zakwalifikowanie jej do jednej z czterech grup: 1) osoby określone seksualnie (stypizowane); 2) osoby androgyniczne; 3) osoby nieokreślone seksualnie; 4) osoby krzyżowo określone seksualnie. Inwentarz do Oceny Płci Psychologicznej cechuje się korzystnymi własnościami psychometrycznymi. Współczynniki rzetelność IPP mierzone metodą estymacji wewnętrznej wyniosły dla skali Kobiecości 0,7856, a dla skali Męskości 0,7834. Za zadowalające uznano również wskaźniki trafności teoretycznej ocenionej na podstawie wyników badania Inwentarzem do Oceny Płci Psychologicznej osób transseksualnych (Kuczyńska, 1992, s. 21- 24).

W badaniach wzięło udział 87 osób, w tym 51 kobiet i 36 mężczyzn. Badane osoby były w wieku od 18 do 30 lat. Poszerzono przedział wiekowy i grupę badaną o osoby znajdujące się na progu wczesnej dorosłości i w pierwszej jej fazie. Badania przeprowadzono w formie internetowej, za pomocą internetowego programu z pakietu Google. Ilościową analizę wyników obliczono za pomocą

\footnotetext{
${ }^{1}$ Badania przeprowadziła A. Jarząbek w ramach pracy magisterskiej: Czystość przedmałżeńska młodzieży różniącej się poczuciem tożsamości płciowej, pisanej pod kierunkiem D. Opozdy, Arch. BU KUL, Lublin 2021.
} 
programu SPSS (policzono: $\chi^{2}$ ). Podział grupy z uwagi na poczucie tożsamości płciowej przedstawia tabela 1 .

Tabela 1. Typ poczucia tożsamości płciowej badanych - procentowy rozkład wyników w skali IPP

\begin{tabular}{|l|c|c|c|c|c|c|}
\hline \multirow{2}{*}{} & \multicolumn{2}{|c|}{ Kobiety $(\mathrm{N}=51)$} & \multicolumn{2}{c|}{ Mężczyźni $(\mathrm{N}=36)$} & \multicolumn{2}{c|}{ Razem (N=87) } \\
\cline { 2 - 7 } & $\mathrm{N}$ & $\%$ & $\mathrm{~N}$ & $\%$ & $\mathbf{N}$ & $\%$ \\
\hline Stypizowany & 30 & 59 & 1 & 3 & $\mathbf{3 1}$ & 36 \\
\hline Androgyniczny & 5 & 10 & 15 & 42 & $\mathbf{2 0}$ & 23 \\
\hline Krzyżowo określony & 3 & 6 & 8 & 22 & $\mathbf{1 1}$ & 12 \\
\hline Nieokreślony & 13 & 25 & 12 & 33 & $\mathbf{2 5}$ & 29 \\
\hline Razem & 51 & 100 & 36 & 100 & $\mathbf{8 7}$ & 100 \\
\hline
\end{tabular}

\section{WYNIKI I WNIOSKI Z BADAŃ}

Z racji wielości wyników i ograniczenia objętości tekstu w niniejszym komunikacie przedstawiam jedynie przykładowe wyniki, które sygnalizować mogą pewne kierunki powiązań. Obliczenia są jedynie procentowe i nie mogą stanowić podstaw do formułowania twierdzeń o związkach między zmiennymi. Mają więc one charakter przyczynkarski. Kolejno prezentuję opinię badanej młodzieży dotyczącą wybranych aspektów czystości przedmałżeńskiej, bez rozróżnienia na płeć biologiczną.

Rozumienie czystości małżeńskiej badanych kolejno obrazują tabele 2 i 3.

Tabela 2. Rozumienie czystości przedmałżeńskiej

\begin{tabular}{|c|c|c|c|c|c|c|c|c|c|c|}
\hline \multirow{3}{*}{$\begin{array}{l}\text { Czystość } \\
\text { przedmałżeńska to: } \\
\text { wstrzemięźliwość } \\
\text { seksualna }\end{array}$} & \multicolumn{2}{|c|}{ Stypizowany } & \multicolumn{2}{|c|}{ Androgyniczny } & \multicolumn{2}{|c|}{$\begin{array}{l}\text { krzyżowo } \\
\text { określony }\end{array}$} & \multicolumn{2}{|c|}{ Nieokreślony } & \multicolumn{2}{|c|}{ Ogółem } \\
\hline & $\mathrm{N}$ & $\%$ & $\mathrm{~N}$ & $\%$ & $\mathrm{~N}$ & $\%$ & $\mathrm{~N}$ & $\%$ & $\mathrm{~N}$ & $\%$ \\
\hline & 14 & 45 & 14 & 70 & 10 & 91 & 18 & 72 & 56 & 65 \\
\hline $\begin{array}{l}\text { wstrzemięźliwość, } \\
\text { dbanie o myśli, słowa, } \\
\text { podmiotowe traktowanie }\end{array}$ & 15 & 49 & 4 & 20 & 1 & 9 & 6 & 24 & 26 & 30 \\
\hline nie uznaję tego & 1 & 3 & 0 & 0 & 0 & 0 & 0 & 0 & 1 & 1 \\
\hline $\begin{array}{l}\text { niemieszkanie razem } \\
\text { przed ślubem }\end{array}$ & 1 & 3 & 1 & 5 & 0 & 0 & 0 & 0 & 2 & 2 \\
\hline brak odpowiedzi & 0 & 0 & 1 & 5 & 0 & 0 & 1 & 4 & 2 & 2 \\
\hline
\end{tabular}


Tabela 3. Przejawy czystości przedmałżeńskiej

\begin{tabular}{|l|c|c|c|c|c|c|c|c|c|c|}
\hline \multirow{2}{*}{$\begin{array}{c}\text { Czystość przedmałżeńska } \\
\text { przejawia się: }\end{array}$} & \multicolumn{2}{|c|}{ Stypizowany } & \multicolumn{2}{|c|}{ Androgyniczny } & \multicolumn{2}{|c|}{$\begin{array}{c}\text { krzyżowo } \\
\text { określony }\end{array}$} & \multicolumn{2}{|c|}{ Nieokreślony } & \multicolumn{2}{|c|}{ Ogółem } \\
\cline { 2 - 12 } $\begin{array}{l}\text { wyłącznie przez } \\
\text { powstrzymanie się od } \\
\text { współżycia przed ślubem. }\end{array}$ & 8 & 26 & 11 & 55 & 6 & 55 & 12 & 48 & 37 & 43 \\
\cline { 2 - 12 } & $\mathrm{N}$ & $\%$ & $\mathrm{~N}$ & $\%$ & $\mathrm{~N}$ & $\%$ & $\mathrm{~N}$ & $\%$ & $\mathrm{~N}$ & $\%$ \\
\hline $\begin{array}{l}\text { nie tylko przez } \\
\text { powstrzymanie się od } \\
\text { współżycia przed ślubem. }\end{array}$ & 23 & 74 & 9 & 45 & 5 & 45 & 13 & 52 & 50 & 57 \\
\hline
\end{tabular}

Powyższe wyniki wskazują, że młodzież stypizowana, czyli silnie identyfikująca się z wzorcami kulturowymi, zgodnymi z ich płcią biologiczną, czystość przedmałżeńską rozumie szerszej niż tylko wstrzemięźliwość seksualną. Świadczyć to może o głębszym rozumieniu seksualności człowieka i większej wrażliwości moralnej.

Tabela 4. Środowiska kształtujące opinie na temat czystości przedmałżeńskiej

\begin{tabular}{|l|c|c|c|c|c|c|c|c|c|c|}
\hline \multirow{2}{*}{ Czynniki } & \multicolumn{2}{|c|}{ Stypizowany } & \multicolumn{2}{|c|}{ Androgyniczny } & \multicolumn{2}{c|}{$\begin{array}{c}\text { krzyżowo } \\
\text { określony }\end{array}$} & \multicolumn{2}{|c|}{ Nieokreślony } & \multicolumn{2}{|c|}{ Ogółem } \\
\cline { 2 - 15 } & $\mathrm{N}$ & $\%$ & $\mathrm{~N}$ & $\%$ & $\mathrm{~N}$ & $\%$ & $\mathrm{~N}$ & $\%$ & $\mathrm{~N}$ & $\%$ \\
\cline { 2 - 15 } Rodzina & 25 & 80 & 10 & 50 & 8 & 72 & 15 & 60 & 58 & 67 \\
\hline $\begin{array}{l}\text { Szkoła :(postawy } \\
\text { nauczycieli) }\end{array}$ & 3 & 10 & 4 & 20 & 1 & 9 & 5 & 20 & 13 & 15 \\
\hline Kościół & 28 & 90 & 16 & 80 & 9 & 82 & 20 & 80 & 73 & 84 \\
\hline Rówieśnicy & 8 & 26 & 6 & 30 & 3 & 27 & 5 & 20 & 22 & 25 \\
\hline Media & 4 & 13 & 4 & 20 & 1 & 9 & 6 & 24 & 15 & 17 \\
\hline Wspólnota & 1 & 3 & 0 & 0 & 0 & 0 & 1 & 4 & 2 & 2 \\
\hline Nikt & 0 & 0 & 0 & 0 & 1 & 9 & 0 & 0 & 1 & 1 \\
\hline Własne przemyślenia & 1 & 3 & 1 & 5 & 0 & 0 & 1 & 4 & 3 & 3 \\
\hline
\end{tabular}

W każdej grupie największe znaczenie w kształtowaniu opinii na temat czystości przedmałżeńskiej ma nauczanie Kościoła. Drugą najczęściej udzielaną odpowiedzią jest rodzina, przy czym osoby androgyniczne znaczenie rodziny przypisują w mniejszym stopniu niż pozostali.

Poniżej tabele obrazują opinię młodzieży na temat znaczenia (korzyści i straty) czystości małżeńskiej. 
Tabela 5. Korzyści płynące z życia w czystości przedmałżeńskiej według badanej młodzieży

\begin{tabular}{|l|c|c|c|c|c|c|c|c|c|c|}
\hline \multirow{2}{*}{ Korzyści } & \multicolumn{2}{|c|}{ Stypizowany } & \multicolumn{2}{|c|}{ Androgyniczny } & \multicolumn{2}{c|}{$\begin{array}{c}\text { Krzyżowo } \\
\text { określony }\end{array}$} & \multicolumn{2}{c|}{ Nieokreślony } & \multicolumn{2}{c|}{ Ogółem } \\
\cline { 2 - 14 } & $\mathrm{N}$ & $\%$ & $\mathrm{~N}$ & $\%$ & $\mathrm{~N}$ & $\%$ & $\mathrm{~N}$ & $\%$ & $\mathrm{~N}$ & $\%$ \\
\cline { 2 - 14 } & 24 & 77 & 12 & 60 & 8 & 73 & 20 & 80 & 64 & 74 \\
\hline $\begin{array}{l}\text { Umacnia więź } \\
\text { choroni przed }\end{array}$ & 3 & 10 & 7 & 35 & 2 & 6 & 7 & 28 & 19 & 22 \\
\hline $\begin{array}{l}\text { Unikanie zranień } \\
\text { emocjonalnych }\end{array}$ & 14 & 45 & 7 & 35 & 5 & 45 & 13 & 52 & 39 & 45 \\
\hline $\begin{array}{l}\text { Zwiększa poczucie } \\
\text { własnej wartości }\end{array}$ & 7 & 23 & 2 & 10 & 4 & 36 & 4 & 16 & 17 & 20 \\
\hline Daje wolność wyboru & 7 & 23 & 10 & 50 & 1 & 9 & 11 & 44 & 29 & 33 \\
\hline $\begin{array}{l}\text { Pomaga } \\
\text { w dochowaniu } \\
\text { wierności }\end{array}$ & 15 & 48 & 8 & 40 & 5 & 45 & 13 & 52 & 41 & 47 \\
\hline Wzmacnia zaufanie & 22 & 71 & 8 & 40 & 7 & 64 & 11 & 44 & 48 & 55 \\
\hline $\begin{array}{l}\text { Uczy prawdziwej } \\
\text { miłości }\end{array}$ & 1 & 3 & 0 & 0 & 0 & 0 & 0 & 0 & 1 & 1 \\
\hline Pogłębia wiarę & 1 & 3 & 0 & 0 & 0 & 0 & 0 & 0 & 1 & 1 \\
\hline $\begin{array}{l}\text { Uczy siły woli } \\
\text { i odmawiania sobie } \\
\text { przyjemności }\end{array}$ & 0 & 0 & 0 & 0 & 0 & 0 & 1 & 4 & 1 & 1 \\
\hline
\end{tabular}

Tabela 6. Dlaczego zachowywanie czystości przedmałżeńskiej może być niekorzystne?

\begin{tabular}{|l|c|c|c|c|c|c|c|c|c|c|}
\hline \multirow{2}{*}{ Nie można: } & \multicolumn{2}{|c|}{ Stypizowany } & \multicolumn{2}{|c|}{ Androgyniczny } & \multicolumn{2}{c|}{$\begin{array}{c}\text { Krzyżowo } \\
\text { określony }\end{array}$} & \multicolumn{2}{c|}{ Nieokreślony } & \multicolumn{2}{c|}{ Ogółem } \\
\cline { 2 - 13 } & $\mathrm{N}$ & $\%$ & $\mathrm{~N}$ & $\%$ & $\mathrm{~N}$ & $\%$ & $\mathrm{~N}$ & $\%$ & $\mathrm{~N}$ & $\%$ \\
\cline { 2 - 13 } $\begin{array}{l}\text { mieć pewności, że się } \\
\text { do siebie pasuje }\end{array}$ & 10 & 32 & 10 & 50 & 5 & 45 & 9 & 36 & 34 & 39 \\
\hline $\begin{array}{l}\text { cieszyć się z bycia } \\
\text { razem }\end{array}$ & 8 & 26 & 9 & 45 & 1 & 9 & 7 & 28 & 25 & 29 \\
\hline $\begin{array}{l}\text { razem zamieszkać } \\
\text { przed ślubem }\end{array}$ & 10 & 32 & 6 & 30 & 6 & 55 & 7 & 28 & 29 & 33 \\
\hline $\begin{array}{l}\text { Nie dostrzegam } \\
\text { minusów }\end{array}$ & 12 & 39 & 3 & 15 & 3 & 27 & 6 & 24 & 24 & 28 \\
\hline Zdrady & 0 & 0 & 1 & 5 & 0 & 0 & 1 & 4 & 2 & 2 \\
\hline $\begin{array}{l}\text { Niespełnianie } \\
\text { naturalnych potrzeb }\end{array}$ & 1 & 3 & 3 & 15 & 1 & 9 & 1 & 4 & 6 & 7 \\
\hline
\end{tabular}

Wszyscy badani upatrują korzyści w rozwijaniu więzi, osoby stypizowane i krzyżowo określone doceniają dodatkowo wzmacnianie wzajemnego zaufania. 
Ogólnie, można wnioskować, że w opinii badanych czystość przedmałżeńska sprzyja relacjom osobowym. Natomiast jej zachowywanie może być niekorzystne z uwagi na niepewność co do dopasowania do siebie (stypizowani, androgyniczni i nieokreśleni) oraz utrudnia zamieszkanie przed ślubem (stypizowani i krzyżowo określeni). Osoby stypizowane w najwyższym stopniu nie wskazują na minusy zachowania czystości przedmałżeńskiej.

Tabela 7. Motywy zachowania czystości przedmałżeńskiej

\begin{tabular}{|c|c|c|c|c|c|c|c|c|c|c|}
\hline \multirow[b]{3}{*}{$\begin{array}{l}\text { Jest to moje } \\
\text { wewnętrzne } \\
\text { przekonanie }\end{array}$} & \multicolumn{2}{|c|}{ Stypizowany } & \multicolumn{2}{|c|}{ Androgyniczny } & \multicolumn{2}{|c|}{$\begin{array}{l}\text { Krzyżowo } \\
\text { określony }\end{array}$} & \multicolumn{2}{|c|}{ Nieokreślony } & \multicolumn{2}{|c|}{ Ogółem } \\
\hline & $\mathrm{N}$ & $\%$ & $\mathrm{~N}$ & $\%$ & $\mathrm{~N}$ & $\%$ & $\mathrm{~N}$ & $\%$ & $\mathrm{~N}$ & $\%$ \\
\hline & 24 & 77 & 8 & 40 & 5 & 45 & 21 & 84 & 58 & 67 \\
\hline $\begin{array}{l}\text { Kieruję się wiarą } \\
\text { katolicką }\end{array}$ & 26 & 84 & 10 & 50 & 9 & 82 & 17 & 68 & 62 & 71 \\
\hline $\begin{array}{l}\text { Tak zostałem/-łam } \\
\text { wychowana }\end{array}$ & 22 & 71 & 8 & 40 & 6 & 55 & 17 & 68 & 53 & 61 \\
\hline $\begin{array}{l}\text { Kieruję się opinią } \\
\text { rówieśników }\end{array}$ & 2 & 6 & 1 & 5 & 2 & 18 & 5 & 20 & 10 & 11 \\
\hline $\begin{array}{l}\text { Podzielam przekonanie } \\
\text { mojej rodziny }\end{array}$ & 6 & 19 & 3 & 15 & 4 & 36 & 5 & 20 & 18 & 21 \\
\hline Nie chcę zachować & 4 & 13 & 8 & 40 & 2 & 18 & 5 & 20 & 19 & 22 \\
\hline $\begin{array}{l}\text { Chcę, aby moja relacją } \\
\text { była budowana na } \\
\text { mocnym fundamencie }\end{array}$ & 1 & 3 & 0 & 0 & 0 & 0 & 0 & 0 & 1 & 1 \\
\hline $\begin{array}{l}\text { Pragnę pięknej i czystej } \\
\text { miłości }\end{array}$ & 1 & 3 & 0 & 0 & 0 & 0 & 0 & 0 & 1 & 1 \\
\hline $\begin{array}{l}\text { Chcę zaufać drugiej } \\
\text { osobie }\end{array}$ & 0 & 0 & 0 & 0 & 1 & 9 & 0 & 0 & 1 & 1 \\
\hline $\begin{array}{l}\text { Boję się seksu } \\
\text { odkładam to na później }\end{array}$ & 0 & 0 & 0 & 0 & 0 & 0 & 1 & 4 & 1 & 1 \\
\hline $\begin{array}{l}\text { Pragnę być dobrym (ą), } \\
\text { odpowiedzialnym (ą) } \\
\text { mężem/żoną }\end{array}$ & 0 & 0 & 0 & 0 & 0 & 0 & 1 & 4 & 1 & 1 \\
\hline
\end{tabular}

Wiara katolicka i wychowanie są czynnikami motywującymi do zachowania czystości u wszystkich osób. W opinii osób androgynicznych zauważyć można tendencję do liberalizacji tej wartości. Widoczna jest ona również w odpowiedzi badanych na pytanie czy chcą żyć według zasady czystości przedmałżeńskiej i czy zgodnie z nią będą wychowywać swoje dzieci (tabela 8 i 9). 
Tabela 8. Czy chcesz żyć według zasady czystości przedmałżeńskiej?

\begin{tabular}{|c|c|c|c|c|c|c|c|c|c|c|}
\hline \multirow{2}{*}{ Skala } & \multicolumn{2}{|c|}{ Stypizowany } & \multicolumn{2}{|c|}{ Androgyniczny } & \multicolumn{2}{|c|}{$\begin{array}{l}\text { Krzyżowo } \\
\text { określony }\end{array}$} & \multicolumn{2}{|c|}{ Nieokreślony } & \multicolumn{2}{|c|}{ Ogółem } \\
\hline & $\mathrm{N}$ & $\%$ & $\mathrm{~N}$ & $\%$ & $\mathrm{~N}$ & $\%$ & $\mathrm{~N}$ & $\%$ & $\mathrm{~N}$ & $\%$ \\
\hline Zdecydowanie nie & 1 & 3 & 3 & 15 & 1 & 9 & 2 & 8 & 7 & 8 \\
\hline $\mathrm{Nie}$ & 3 & 10 & 3 & 15 & 2 & 18 & 2 & 8 & 10 & 11 \\
\hline Nie wiem & 4 & 13 & 4 & 20 & 0 & 0 & 7 & 28 & 15 & 17 \\
\hline Tak & 12 & 39 & 3 & 15 & 2 & 18 & 5 & 20 & 22 & 25 \\
\hline Zdecydowanie tak & 11 & 35 & 7 & 35 & 6 & 55 & 9 & 36 & 33 & 39 \\
\hline
\end{tabular}

Tabela 9. Czy zgodnie z zasadą czystości przedmałżeńskiej chcesz wychowywać swoje dzieci?

\begin{tabular}{|l|c|c|c|c|c|c|c|c|c|c|}
\hline \multirow{3}{*}{ Decyzja } & \multicolumn{2}{|c|}{ Stypizowany } & \multicolumn{2}{|c|}{ Androgyniczny } & \multicolumn{2}{c|}{$\begin{array}{c}\text { Krzyżowo } \\
\text { określony }\end{array}$} & \multicolumn{2}{c|}{ Nieokreślony } & \multicolumn{2}{c|}{ Ogółem } \\
\cline { 2 - 13 } & $\mathrm{N}$ & $\%$ & $\mathrm{~N}$ & $\%$ & $\mathrm{~N}$ & $\%$ & $\mathrm{~N}$ & $\%$ & $\mathrm{~N}$ & $\%$ \\
\cline { 2 - 13 } Nie & 5 & 16 & 9 & 45 & 2 & 18 & 8 & 32 & 24 & 28 \\
\hline Tak & 26 & 84 & 11 & 55 & 9 & 82 & 17 & 68 & 63 & 72 \\
\hline
\end{tabular}

Badana młodzież wyraża opinię, że czystość przedmałżeńska jest w obecnych czasach potrzebna, uzasadniają to wyniki dotyczące korzyści płynące z zachowania tej wartości.

Tabela 10. Opinie badanej młodzieży na temat tego, czy zachowanie czystości przedmałżeńskiej jest potrzebne dzisiaj

\begin{tabular}{|l|c|c|c|c|c|c|c|c|c|c|}
\hline \multirow{2}{*}{ Skala } & \multicolumn{2}{|c|}{ Stypizowany } & \multicolumn{2}{|c|}{ Androgyniczny } & \multicolumn{2}{c|}{$\begin{array}{c}\text { krzyżowo } \\
\text { określony }\end{array}$} & \multicolumn{2}{c|}{ Nieokreślony } & \multicolumn{2}{c|}{ Ogółem } \\
\cline { 2 - 13 } & $\mathrm{N}$ & $\%$ & $\mathrm{~N}$ & $\%$ & $\mathrm{~N}$ & $\%$ & $\mathrm{~N}$ & $\%$ & $\mathrm{~N}$ & $\%$ \\
\cline { 2 - 13 } Zdecydowanie nie & 2 & 7 & 2 & 10 & 1 & 9 & 0 & 0 & 5 & 6 \\
\hline Nie & 1 & 3 & 5 & 25 & 0 & 0 & 3 & 12 & 9 & 10 \\
\hline Nie wiem & 2 & 6 & 3 & 15 & 2 & 18 & 6 & 24 & 13 & 15 \\
\hline Tak & 11 & 36 & 3 & 30 & 1 & 9 & 6 & 24 & 21 & 24 \\
\hline Zdecydowanie tak & 15 & 48 & 7 & 35 & 7 & 64 & 10 & 40 & 39 & 45 \\
\hline
\end{tabular}

\section{PODSUMOWANIE}

Na podstawie obliczeń procentowych należy z ostrożnością formułować wnioski z badań. Różnice międzygrupowe okazały się nieistotne statystycznie, co prowadzi do stwierdzenia, że nie zachodzi istotny związek między poczuciem tożsamości 
płciowej badanych a ich opinią na temat czystości przedmałżeńskiej - badania nie potwierdziły założonej hipotezy. Jednakże procentowe wyniki uzyskane w toku badania opinii młodzieży na temat czystości przedmałżeńskiej w pewnym zarysie dają obraz przekonań badanych i zachęcają do dalszych poszukiwań w tym kierunku. Opinia badanych na temat czystości przedmałżeńskiej jest pozytywna i wyraża po części akceptację dla zachowań zgodnych z tą wartością. Większą aprobatę dla wartości czystości przedmałżeńskiej wyrażają osoby identyfikujące się z wzorcem kulturowym zgodnym z ich płcią biologiczną (stypizowani). Opinię podobną do nich częściej posiadają osoby krzyżowo określone. Odmienną natomiast osoby androgyniczne. Osoby stypizowane są prawdopodobnie bardziej przywiązane do tradycji w pełnieniu ról rodzinnych, stylów życia i zasad, które je określają. Osoby androgyniczne zaś są aschematyczne i wykraczają poza kulturowe standardy, dlatego należy sądzić, że wyniki badań bardzo wstępnie podają w wątpliwość zasadę globalnej użyteczności androgynii psychicznej, która - jak pokazują inne badania - tylko fragmentarycznie sprawdza się w obszarze wychowania (Opozda, 2012). O ile bardziej czytelne są dane empiryczne dotyczące osób stypizowanych i androgynicznych, o tyle mniej jasne, ale i w związku z tym interesujące są dane dotyczące osób krzyżowo określonych i nieokreślonych. Zauważyć trzeba, że grupa badana była zbyt mało liczna, a więc trudno przy niskiej liczebności w podgrupach uzyskać zadowalające dane empiryczne, które mogłyby wyraźniej wskazywać na tendencje czy związki między zmiennymi. Zwiększenie liczby badanych umożliwiłoby prowadzenie analiz w ramach grup wyodrębnionych także z uwagi na płeć biologiczną oraz kontrolowanie związków korelacyjnych między wartością zmiennej niezależnej (wyniki w skalach kobiecości i męskości) a zmienną zależną. Jest to wciąż nieodkryty obszar w oglądzie badań pedagogicznych.

\section{BIBLIOGRAFIA}

BEM, S.L. (2000). Męskość, kobiecość: o różnicach wynikajacych z ptci (tł. S. Pikiel). Gdańsk: GWP. DzIEwIECKI, M. (2006). Ona, on i milość. Kraków: Wydawnictwo eSPe.

DzIewiecki, M. (2011). Problemy z seksualnościa. Kraków: Wydawnictwo eSPe.

JAN PAWEe II (1986). Mężczyzną i niewiastą stworzył ich. Chrystus odwołuje się do „początku”. W: T. STYCzeń (red.), Mężczyzna i niewiasta stworzyt ich. Chrystus odwoluje się do "początku” (O Jana Pawła II teologii ciała) (19-85). Lublin: Redakcja Wydawnictw KUL.

JARZĄBEK, A. (2021). Czystość przedmałżeńska młodzieży różniącej się poczuciem tożsamości płciowej, praca magisterska pod kier. D. Opozdy. Lublin: Arch. WNS KUL.

JAZUKIEwicz, I., RoJewsKa, E. (red.). (2017). Sprawności moralne w wychowaniu: odpowiedzialność - wierność - postuszeństwo. Szczecin: Wydawnictwo USz. 
Katechizm Kościoła Katolickiego (1994). Poznań: Wydawnictwo Pallottinum.

Mandal, M. (2003). Kobiecość i męskość. Popularne opinie a badania naukowe. Warszawa: Wydawnictwo Akademickie „Żak”.

Melosik, Z. (2013). Kultura popularna i tożsamość młodzieży. W niewoli władzy i wolności. Kraków: Oficyna Wydawnicza Impuls.

KuCZyŃsKa, A. Inwentarz do oceny płci psychologicznej. Podręcznik. Warszawa: Pracownia Testów Psychologicznych PTP.

MilusKa, J. (1996). Tożsamość kobiet i mężczyzn w cyklu życia. Poznań: WN UAM.

OpozDA, D. (2012). Struktura i treść jednostkowej wiedzy o wychowaniu. Studium pedagogiczne wiedzy rodziców i jej korelatów. Lublin: TN KUL.

OstrowsKa, U. (2017). Wierność z perspektywy aksjologicznej. W: I. JAZUKIEWICZ, E. RoJEwskA (red.), Sprawności moralne $w$ wychowaniu: odpowiedzialność - wierność - postuszeństwo. Szczecin: Wydawnictwo USz.

Skrzydlewski, P. (2021). Cnoty niewieście. Ateneum Kapłańskie, 2(675), 214-231.

Wojciszke, B. (2002). Człowiek wśród ludzi. Zarys psychologii społecznej. Warszawa: Wydawnictwo Naukowe Scholar.

WojtYŁa, K. (1982). Miłość i odpowiedzialność. Lublin: TN KUL.

\section{CZYSTOŚĆ JAKO WARTOŚĆ W OPINII MŁODZIEŻY \\ O RÓŻNYM POCZUCIU TOŻSAMOŚCI PŁCIOWEJ \\ W ŚWIETLE BADAŃ PILOTAŻOWYCH}

Celem artykułu jest przedstawienie opinii młodzieży na temat czystości przedmałżeńskiej jako wartości. Artykuł ma formę komunikatu z przeprowadzonych badań, które miały charakter pilotażowy. Przedmiotem poznania prezentowanych badań była wartość czystości w opinii młodzieży. W badaniach uwzględniono poczucie tożsamości płciowej młodzieży.

Słowa kluczowe: czystość przedmałżeńska; wartość; młodzież; poczucie tożsamości płciowej.

\section{CHASTITY AS A VALUE IN THE OPINION OF YOUNG PEOPLE WITH DIFFERENT SENSES OF GENDER IDENTITY IN THE LIGHT OF PILOT RESEARCH}

\section{SUMMARY}

The aim of the article is to present the views of young people on premarital chastity as a value. The article is in the form of a communication from the conducted research, which was of a pilot nature. The subject of learning about the presented research was the value of cleanliness in the opinion of young people. The research took into account the sense of gender identity in adolescents.

Keywords: premarital chastity; value; youth; sense of gender identity. 